М.М. Зеркаль

\title{
ЖАХЛИВІ ПРОЯВИ РЕПРЕСІЙ ПЕРЕСІЧНОГО НАСЕЛЕННЯ ПІД ЧАС ГОЛОДОМОРУ 1932-1933 РР. В РЕГІОНАЛЬНОМУ ВИМІРІ (МИКОЛАЇв)
}

Автором досліджуються архівні кримінальні справи репресованих мешканців Миколаївщини в умовах голодомору 1932 - 1933 роках. Здійснюється спроба звернути увагу читачів не просто до статистики жертв тоталітарного радянського режиму, а дослідити проблему тотального фізичного знищення україниів, росіян, представників інших етнічних меншин які мешкали в Південному регіоні, до сфабрикованих співробітниками правоохоронних органів справ та вщанування пам'яті невинних жертв, про яких залишились, в більшості випадків, лище кримінальні справи і одночасно віддати данину поваги до замордованих голодом $i$ не зафіксованих на сторінках документів. Розкривається антигуманний, протиправний характер діяльності слідчих та судових органів в справі тотального знищення селянства Півдня України.

Ключові слова: тоталітарна система, злочин, геноцид, голодомор, партійний апарат, ідеологія, селянство.

Голодомор - завжди трагедія і забувати про неї неможливо ні на хвилину. Випробування українського народу вже набуло певного висвітлення в наукових доробках, де головну увагу сконцентровано саме на кількості вивезеного збіжжя та померлих від голоду людей. Останнім часом здійснюються також спроби дослідження інших аспектів проведення політики етнічного геноциду українців, наприклад вилучення матеріальних цінностей у населення, нищення спроб опору не лише під час повстань 
силами регулярної армії, а також запровадження масових репресій по відношенню до можливих керівників антирадянських рухів збройного опору. Процес повернення історичної пам'яті сьогодні надзвичайно важливо підтримувати та забезпечувати державну підтримку наукових досліджень та поширювати здобуті напрацювання серед як можна ширшого кола населення.

Пережиту трагедію голодомору 1932-1933 рр. в Україні однією 3 перших досліджувала збірка документів: «Голод 1932-1933 років на Україні: очима істориків, мовою документів» [38]. Це була лише збірка копій окремих державних офіційних документів якими визнавався сам факт голоду. До цього, всі вони мали статус засекречених. Наприкінці 1990-х років українці отримали можливість самостійно ознайомитись 3 документами i почати аналізувати факти. В 1991 р. виходить друком книга-меморіал «33-й: ГОЛОД» [99]. Це була перша спроба альтернативними методами, порівняно 3 офіційною історичною наукою за допомогою усної історії засвідчити вчинені злочини та визначити роль конкретних катів у вчиненому масовому знищенні українців. Всю роботу при підготовці та виданні здійснили Володимир Маняк та Лідія Коваленко. В 1992р. як упорядники Г.М. Михайличенко і Є.П. Шаталін видають наступну збірку документів i матеріалів по голодомору на Миколаївщині [44].

Значною на регіональному рівні стала колективна праця В.П. Шкварця і М.Ф. Мельника «Миколаївщина: погляд крізь століття. Нарис історії»,1994 p. В 1996р. виходить невеликим накладом навчальний посібник для учнів загальноосвітніх шкіл області «Історія Миколаївщини» П.М. Тригуба, І.С. Павлика, О.В. Білюка [80]. В цьому виданні у доступній для відповідної вікової категорії читачів формі було проаналізовано та узагальнено причини i наслідки голодомору 1932-33 рр. на матеріалах Миколаївської області

Державний архів Миколаївської області у 2000 р. видає збірку документів і матеріалів «Миколаївщина: колективізація сільського господарства і голод (1929-1933)», керівник авторського колективу - М.М. 
Шитюк [92]. В цій роботі науковці та старшокурсники під керівництвом М.М. Шитюка [90, 91, 92, 93, 94, 95, 98] виклали результати опитувань свідків голодомору, жертв злочину радянської тоталітарної державної машини яким пощастило вижити.

Дослідження голодомору 1932-1933 років на Миколаївщині також висвітлювалась в статтях миколаївських істориків Бахтіна А.М. [30, 31, 31], Є.Г. Горбурова [94], Т.В. Березовської, Ю.В. Котляра [47], П.І. Соболя [70], I.I,Федькова [82], П.М. Тригуба [80], О.П. Тригуба, Т.В. Березовської, О.М. Юрчика та багатьох інших.

В 2006р. виходить друком колективна монографія М.М. Шитюка і К.Е. Горбурова «Миколаївщина в голодних 1921-1923, 1932-1933, 1946-1947 роках» на сторінках якої було наведено окремі копії історичних архівних документів які нарешті були розсекречені і стали у нагоді для розуміння причин, змісту, економічних і демографічних наслідків цих трагедій [94].

В 2008 році в межах комплексної дослідницької роботи було видано «Національну книгу пам'яті жертв голодомору 1932-1933 років в Україні. Миколаївська область» [58].

В 2015 році виходить навчальний посібник «Історія рідного краю: Миколаївщина» під керівництвом М.М.Шитюка в якому міститься окремий урок № 34 про голодомор 1932-1933 років [100]. Для учнів авторським колективом робиться висновок, що запровадження політики на знищення сільського населення було продуманою політикою радянського апарату у зв'язку з провалом хлібозаготівельної компанії восени 1932 р. До того ж, запровадження «чорних дошок» стало зовнішнім втіленням страшних планів винищення навіть населених пунктів та створення відповідних умов для їх ізоляції і недопущення спроб мігрувати на інші території.

Історіографія дослідження голодомору 1932-1933 рр. на Миколаївщині, як і в цілому по Україні, демонструє певну трансформацію підходів в оцінках від тимчасових і незначних наслідків неврожаю та порушень балансу зовнішньої торгівлі до цілеспрямованої політики тоталітарної держави на 
шляху фізичного знищення інакодумства i знищення найбільш міцного конкурента радянської колективної системи обробітку землі, проведення політики геноциду по відношенню до селян-українців.

Незважаючи на пануючий голод радянська державна машина продовжувала свою роботу по придушенню навіть спроб виявлення невдоволення здійснюваною політикою геноциду. Місцеве населення намагалось вибороти своє право на життя, але середовище страху та жаху, трансформація психіки під впливом голоду забезпечували володарювання радянської системи. Остаточно так i незрозуміло, що виступало мотивувальним аргументом в головах виконавців злочинних наказів, адже всі усвідомлювали та бачили, що всіх виконавців рано чи пізно може чекати доля їх в'язнів. Досліджуючи кримінальні справи, які збереглись до наших днів, типовим прикладом може бути справа групи осіб.

За матеріалами справи №885 ДПУ Одеської області, Миколаївського відділку з 24 листопада 1932 р. по 17 січня 1933р. Станом на 24 листопада 1932 р. Шесточенко Серафім Миколайович був взятий під варту за здійснення серед оточуючих осіб контрреволюційної агітації спрямованої проти заходів Радянського уряду і існуючої економічної системи, підриваючи своїми діями міцність та довіру до Радянської влади, зазначені дії підпадали під дію ст.54-10 КК УРСР [1.-С.1].

Фото. Шесточенко Микола Андрійович

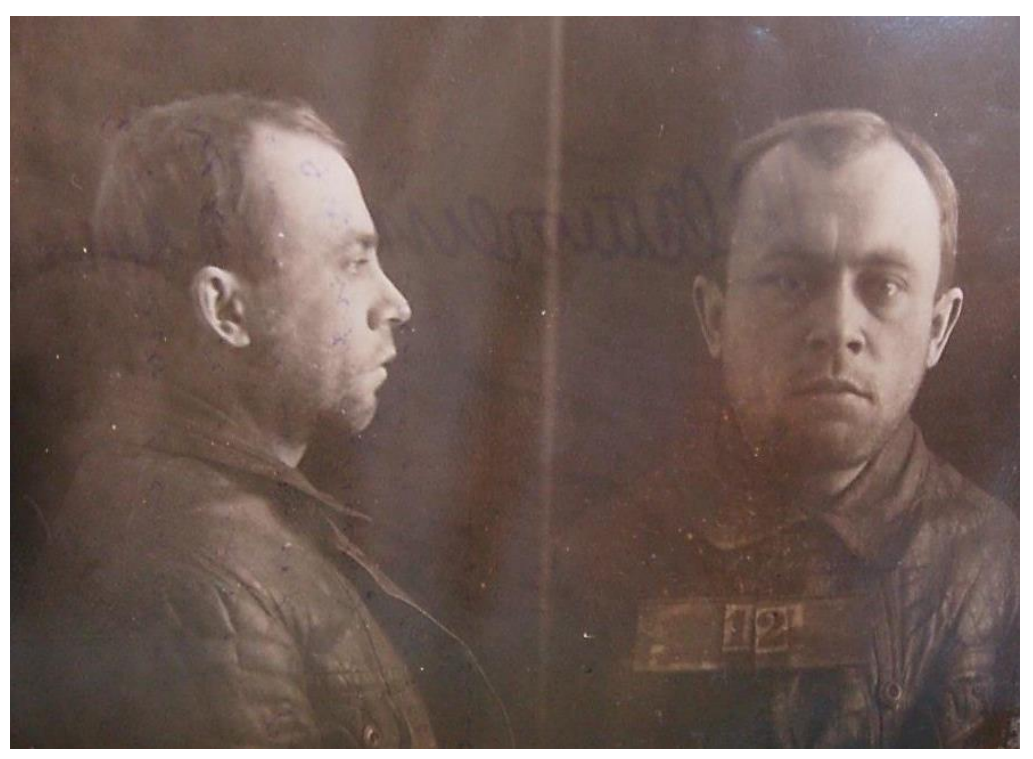

Останній працював касиром-рахівником Миколаївських машиннотракторних майстерень, мешкав в м. Миколаєві, вул. Херсонська буд.19., який народився в 1903 р. в селі Олександрівка Миколаївського району був 
сином Шесточенко Миколи Андрійовича, якому в 1932 р. було 65 років, священик села Олександрівка. В пореволюційний період був розкуркулений, а майно розпродане за несплату податків. Мати - Шесточенко Марія Іванівна 62 років, була домогосподаркою. 31914 по 1917 рр. навчався в м.Херсоні в духовному училищі. Після закінчення навчання знаходився при батькові. В 1921 р. був відряджений ячейкою села Олександрівка до губпарткому на 6 місяців де займав різні посади. Наприкінці 1922 р. добровільно вступає в Червону армію, слід зазначити, що своє походження $з$ родини священика приховав. За його свідченням в 1925 р. перебуваючи в прикордонному отряді на Румунському кордоні, при арешті декількох чоловік і перебуваючи у нетверезому стані побив арештованого, за що і був відданий під суд. Судили його революційним трибуналом в м.Тираспіль і засудили до 5 років тюремного ув'язнення. В 1926 р. був достроково звільнений з ДОПРу. Наприкінці 1926р. вступив в колектив металістів де і пропрацював до 1927 р. В 1927 р. працював на заводі «Незаможник» до 1928 р. 3 початку 1928 р. вступив в колектив електриків де пропрацював до кінця 1930 р. Потім був заарештований Миколаївським міським відділом ДПУ і звільнений в кінці 1931 р. за рішенням суду. 3 кінця 1931 р. вступає в машинно-тракторні майстерні де і пропрацював до арешту. В родині було ще два брати та сестра: Шесточенко Віктор Миколайович - 32 роки, місце перебування було невідомим, Шесточенко Іван Миколайович 19 років також місце перебування було невизначеним, сестра Конюшинська Лідія Миколаївна 26 років, працювала табельницею в Тракторних майстернях та мешкала в Миколаєві за адресою вулиця Херсонська 19. Він був одружений 12 березня 1931 р. на Бобурській (Шесточенко) Марії Іванівні 32 років, дочці великого поміщика, який навіть мав у власності хутір свого власного прізвища та декілька сотень десятин землі - Шило у якої перший чоловік - Бобурський Олександр [1,c.8] був білогвардійським офіцером. Останнього органами ЧК в 1921 р. було розстріляно. 3 майбутньою дружиною познайомився в 1921p. Дружина працювала рахівницею на хімзаводі. Мешкав, на момент ув'язнення в 
Миколаєві по вулиці Херсонській буд.19. В матеріалах справи зазначається, що громадянин УРСР, росіянин за національністю, за освітою мав незакінчене середню, а військовому обліку стояв як молодший керівний склад запасу К-2. Зрозуміло, що вона особисто себе не проявила як ворог нової влади, але «пляма» «дружини ворога» вплинула всю подальшу долю. На час розгляду справи Серафім Миколайович вже був раніше під слідством в 1925 р. за перевищення повноважень, а саме - побиття арештованого перебуваючи в прикордонному загін та засуджений до 5 років ДОПРу. Наступне притягнення до відповідальності сталося в 1931 р. коли він звинувачувався за ст.54-10, але виправданий. 24 листопада 1932 р. було проведено трус співробітниками: Тоното, Савченко, Смеловим, а також громадянином Матвєєнко. Єдине що було вилучено - 9 аркушів листування. В рапорті зазначалось, що прийшли вони до помешкання в 24 годині 23 листопада 1932 р., але звинуваченого вдома не було, вони сиділи до 4 години ранку чекали. Послали т. Савченко до відділу ГПУ з інформацією про стан справ і подальших дій. Отримавши наказ здійснити трус тим і зайнялися. В помешканні була лише сестра звинувачуваного яка зазначала, що: «...мол знаємо ми хто там працює, у вас піддають тортурам людей, ось брат ні за що просидів рік і знову беруть...». О 7 годині ранку прийшов господар 3 дружиною і його взяли під варту [1, с.4].

При першому ж допиті було складено додатковий протокол в якому звинувачений спеціально зазначав, що «ні дружина моя, ні я ніколи не вели розмов спрямованих проти радянської влади і взагалі ніде і ніколи не були присутніми при антирадянських контрреволюційних розмовах. Коли приїздив Петровський до Миколаєва, і чи приїздив взагалі мені невідомо, ніколи розмов 3 приводу його приїзду у мене з дружиною не було» $[1, c .8]$.

За матеріалами справи стає відомо, що основним звинувачувальним аргументом були свідчення свідків, а саме Бабурського Леоніда Івановича, який зазначав, що добре знайомий з звинувачуваним. В своїх свідченнях особливо підкреслював, що «...вони люди, безумовно, антирадянські, які 
відчужуються та засуджують все радянське, неухильно ненавидять радянську владу.» [1,c.10]. Виявилося, що він рідний брат першого чоловіка Марії Іванівни Шесточенко, якого в 1921 р. за контрреволюцію розстріляла Миколаївська ЧК. Типовими для того часу були особисті міркування свідка, які грунтувались виключно на особистому ставленні, але в матеріали справи були внесені, наприклад: « припускаю, що в 1920p. Шесточенко С.М. 3 наміром проник в партію, щоб прикриваючись званням партійця і партійним кваитком, закінчити або отримати освіту собі, а також користуючись знову ж таки партійним квитком, «влаштуватись» при новій владі. Як йому вдалось проникнути до партії, я не чув» [1, с.10 зв.]. Засвідчуючи спільні співбесіди зазначав, що Шесточенко С.М. порівнював теперішній стан селянства 3 кріпацтвом, при чому висловлювався навіть на користь кріпацтва, заявляючи, що тоді селянам жилось краще, незважаючи на те, що вони працювали на поміщиків[1,с.11]. Селяни тоді були ситими і одягненими, а тепер, працюючи в радгоспах та колгоспах пухнуть від голоду. Додавав також, що тепер не лише селяни, а взагалі все населення голодує, вмирає від голоду. Під час бесід наодинці з свідком підсудний жалівся, що не втік в Румунію, коли служив на кордоні в прикордонній частині, що якби він знав, що в Росії буде такий б....., він давно б вже був за кордоном. Навіть потрапивши за грати звинувачений неодноразово співкамерникам розповідав деякі історії про секретну роботу ДПУ, про що він знав з своєї роботи під час служби на кордоні. Наприклад розповів, що іноді за особливим розпорядженням відкривали кордон для переходу на інший бік осіб 3 особливими розвідувальними завданнями і потім у обумовлений час та умовними знаками пропускають їх назад. Розповідав також не один раз, що ДПУ в своїй роботі користується методом «підсажування» в камери до арештованих своїх людей, також під виглядом заарештованих. Чим попереджав співкамерників від зайвих розмов між собою, адже в камері разом 3 ним знаходилось більше десяти осіб і всі вони це чули. 
Другим свідком в цій справі був Конюшинський Володимир Савелійович 1894 р. народження. Він мав нижчу освіту, бідняк, українець, одружений і працював рахівником в центральній майстерні зернорадгоспу ім.Косіора і був одружений на рідній сестрі підсудного.

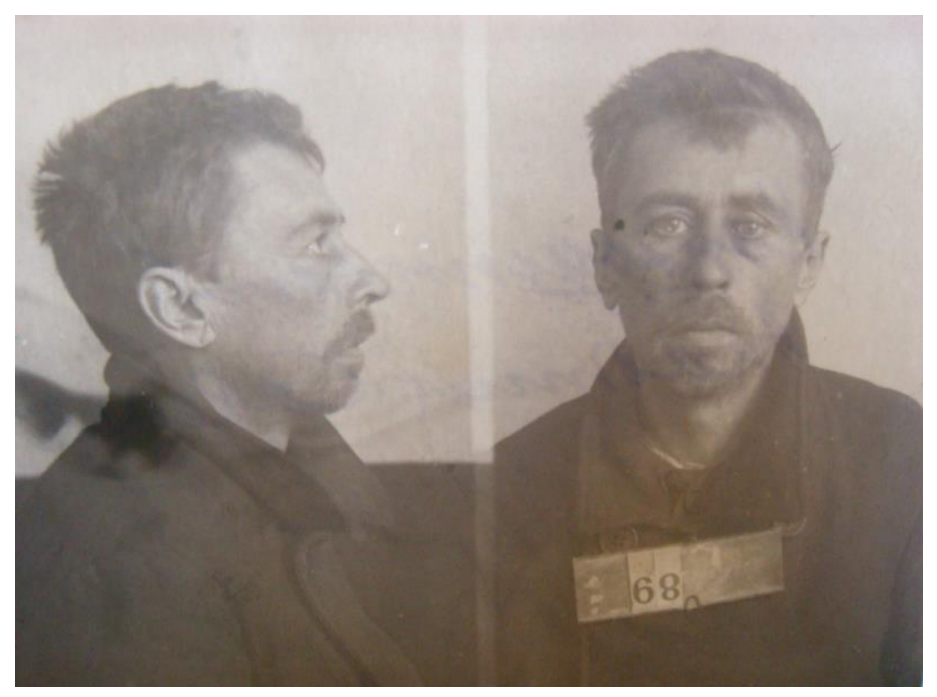

Володимир Савелійович зазначав, що будучи начальником кінної міліції м.Балти Шесточенко С.М. в нетверезому стані порубав арештованого єврея. Він сам запропонував підсудному після звільнення приїхати до нього та своєї сестри. Шесточенко С.М. завдяки тому, що в судових матеріалах зазначив, що його батько вчитель був достроково звільнений. Після приїзду підсудний відразу продемонстрував своє вороже ставлення до радянської влади. Несподіванкою стало те, що він незважаючи на ревнощі повісив на стіні портрет розстріляного першого чоловіка своєї дружини та вважав його мучеником який постраждав за Росію, і на думку свідка був антисемітом. Свої реальні погляди підсудний розкривав лише в знайомому колі та серед родичів. Подружжя визначав як антирадянсько налаштоване, адже заявляли що чекають коли існуючу владу скинуть. «Бандити довели країну до голоду, розорили селян, відправили все за кордон, щоб їх не били й продовжують грабувати, щоб самим залишитись у влади» неодноразово висловлював ці думки підсудний у присутності свідка [Ф.Р5859, Оп.2, Спр.6359.-С.14]. За словами Конюшинського Володимира Савелійовича Шесточенко С.М. в своїх розмовах постійно підкреслював своє негативне ставлення до позик та підписки, зазначаючи, що народ голодує, а 3 нього останні копійки витягають. Свідок також зазначав, що Шесточенко С.М. разом $з$ дружиною постійно висловлювали думку, що вони голодують, а влада облігаціях продати не дозволяє. На час арешту підсудний та його 
дружина проживали без проблем, адже напередодні влітку він таємно придбав у кулака корову. В свідченнях зафіксовано вислів підсудного, що він чекає з нетерпінням зміни влади щоб почати розправу з «жидами», під якими має на увазі всіх комуністів та співчуваючих ним. Його дружина заявляла ніби, що «я сама тоді буду розстрілювати». Особливу увагу слідчі приділили свідченням про те, що підсудний висловлював думку про те, що робітники повинні кидати станки, не працювати, протестувати проти поганого постачання харчами, а селяни щоб не давали державі хліба. За останній час загострилась класова боротьба на селі. Саме тепер, на його думку, склався момент для того, щоб більшовики програли і втратили владу. Навіть зазначалось, що в 1929 р. до м.Миколаєва мав приїхати Петровський i виступити в цирку, на що Шесточенко С.М. висловив ідею принести доповідачу букет із бомбою, а його дружина ніби провокувала свідка також приєднатись до вчинення терористичного акту проти Петровського. Точно ніби свідків назвати ще він не мі, але згадав Бобурського та Бабенко які його підтримували, пиячили. В своїх свідченнях він робив навіть висновок, що : « Шесточенко - ярий, злостний, прихований ворог Радянської влади, який за певних умов здійснював антирадянську агітацію поміж своїх знайомих $\mathrm{i}$ може активно із зброєю в руках виступити проти існуючого порядку. Злість його проти більшовиків доходе до того, що він навіть міркує про терористичні акти проти окремих членів Уряду, як був випадок 3 Петровським. При першій нагоді може втекти за кордон» [1, с.16].

Ще одним свідком в справі проходив Полегенько Петро Фадійович,1895 р. народження, народився та виріс в Миколаєві, середньої освіти, незаможний. В 1920 р. і 1924 р. перебував під слідством за службу у білих але обидва рази засудженим не був. Навіть у своїх свідченнях зазначав що підсудного бачив лише двічі і то побіжно, майже не розмовляв. Але вирішив «просвітити» слідчих з приводу дружини підсудного та iï матері, i зазначив, що при зустрічах 3 ними чув антирадянські висловлювання, які далеко перевищували будь-які межі невдоволення: «.. вони прямо 
засуджують існування радянської влади, бажають йому загибелі, критикують уряд та ін. Це лише різних скарг та невдоволень на голод, відсутність товарів, продовольчого постачання. Вони заявляють, що «народ гине і сподівань на позбавлення немає. «товариші» міцно взяли владу в свої руки..». Також висловлював припущення, що якщо такі розмови ведуться в присутності сторонніх осіб, то в родинному колі і сам Шесточенко С.М. розділяє ці погляди і висловлює аналогічні антирадянські думки [1, с.17]. Більше додати нічого не міг. Отже навіть припущення щодо можливих висловлювань використовували слідчі як доказову базу.

На сторінках справи зафіксоване прізвище слідчого, а саме: уповноважений ОВ Миколаївського міського відділення ДПУ Алютін, нажаль ім'я та по-батькові він не залишив в протоколі допиту. В особистих свідченнях Шесточенко С.М. зазначав, що про контр-революційні організації нічого не знає Антирадянської агітації та розмов не проводив, ні від кого 3 своїх родичів або знайомих не чув.

Сам Серафім Миколайович під час слідства теж не мовчав про своїх знайомих, наприклад він дав свідчення щодо чоловіка своєї сестри Лідії Конюшинського Володимира Савіновича і зазначив що з часу знайомства 3 1926p. знає його як людину глибоко антирадянську, який непримиримо ненавидить все радянське і з нетерпінням очікує зміни влади, державного заколоту, до того ж він антисеміт. Зазначав у свідченнях, що він походить 3 родини поліцейського з великим чином, а сам служив у білих в пошуковому відділенні и здобув навіть чин офіцера. Спілкуючись з Конюшинським В.С. дізнався, що останній досить часто здійснював обшуки у євреїв і забирав цінності, просто грабував і «не потрібні ці копійки які зараз заробляє при радянській владі». 3 приводу державних позик завжди висловлював думку, що на них підписуються лише дурні, що це добровільно-примусові позики і таке інше. Щодо колективізації висловлював думку, що ця політики спричине розорення сільського господарства і спричине загибель селян, що їх змушують колективізуватись, вони дурні раз ідуть до колгоспів і потрібно 
чинити спротив колективізації та ін. Аналогічні висловлювання були і 3 приводу хлібозаготівель, що це розорення, голод і загибель для селян. Багато вів розмов з приводу активного вивезення хліба за кордон і внаслідок чого ми всі голодуємо. Свреїв завжди називав «жидами», висловлював думку що не зможе серед них працювати.

В особистих бесідах зазначав, що Серафім Мколайович хоч і був в Червоній армії, але отримав за це 5 років ДОПРу, зазначав що його недооцінили. Конюшинський будучи українцем за національністю сам негативно ставився до політики українізації.

Одночасно товаришем Глуховим на підставі ордеру №38 від 19 грудня 1932p. було заарештовано Шесточенко (Бабурську) Марію Іванівну за антирадянську агітацію.

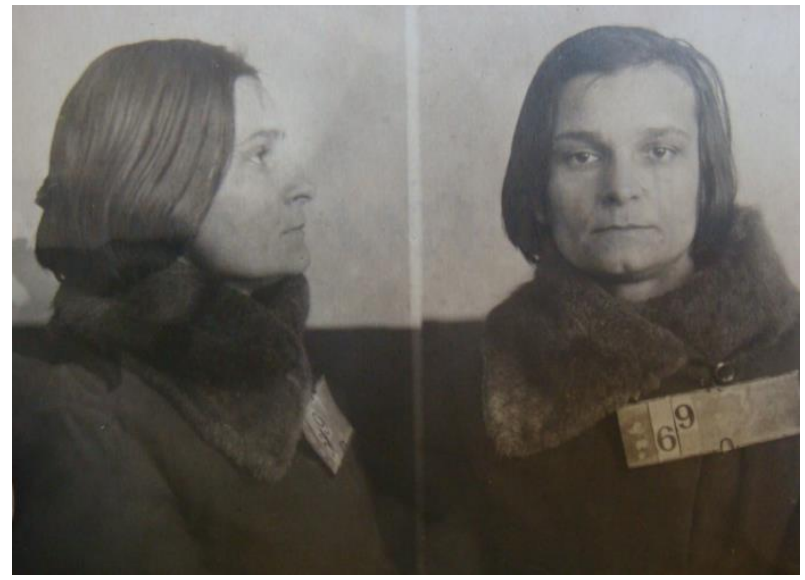

В своїй анкеті додатково до вищезазначеного додала, що освіта середня, безпартійна, українка за національністю, утримує матір Шило Ганну Матвіївну (62роки), син Бабурський Володимир Олександрович 12 років - учень трудшколи[1.с.23]. За матеріалами справи стало відомо, що народилась вона в с. Станіславі ïi батько тоді був торговцем. На початок їі навчання батько залишає дружину і починає спільно жити з поміщицею Шапошніковою, яка володіла власним маєтком, значною кількістю землі та іншого майна, що згодом переписала на батька. 3 початку навчання в м. Миколаєві жила разом 3 матір'ю, яка мала власний будинок, здавала в оренду чиновникам квартири та готувала домашні обіди за рахунок чого i утримувалась. В $1916 \mathrm{p}$. закінчила в м.Миколаїв Маріїнську гімназію і до 1917р. нічим не займалась. В 1917p. вийшла заміж за бувшого офіцера Бабуренко Олександра, який після входу до м. Миколаїв в 1919p. білих вступив до їх лав. На початку 1920p. біля Одеси він потрапляє в полон до Червоної армії. Впродовж місяця 
був під арештом, потім звільнений і направлений в військову частину до м. Кременчуг, але не поїхав і повернувся до м. Миколаєва в сім'ю. В 1920p. приймає участь у повстанні кулаків проти радянської влади в селах Станіслав, Олександрівка та інші. Після придушення повстання він переховувався до січня 1921p. Його було арештовано і через три тижні розстріляно. Марія Іванівна залишалась в м.Миколаїв, жила разом з матір'ю за рахунок наймачів квартир на умовах повного пансіону і почала працювати. В 1928 р. вийшла заміж за Шесточенко Серафіма Миколайовича. Після повернення з ув’язнення іiі чоловік працював рахівником. В останні три роки постійними друзями родини були: Конюшинський В.С. $з$ дружиною(служив у білих в слідчому відділенні), одружений на сестрі чоловіка - Лідії Шесточенко; Щибриков Марк $з$ дружиною, теж бувший офіцер, який служив у білих; Борков Еразм з дружиною, теж бувший офіцер, служив у білих; Стоянов Олександр Павлович, бувший поміщик, має брата офіцера, який на момент слідства перебував за кордоном в білій еміграції; Іванов Михайло 3 дружиною, інженер на заводі, його мати володіє будинком в м. Миколаєві, 3 якого вони напередодні виїхали. Бабенко і Кабанов - співробітники чоловіка, але в останній рік не заходили, Письменна-Бджілкина, Ехат Якович, Різник Михайло - співробітники дружини, які заходили лише один раз.

Під час допитів Марія Іванівна підкреслювала, що ні про які контрреволюційні організації не чула і не знала. 3 приводу антирадянської агітації або антирадянських розмов з свого боку заявила лише те, що мав місце випадок коли перебуваючи в поганому настрої внаслідок важких матеріальних умов висловлювалась на адресу радянської влади, звинувачуючи іiі в тому, що вона неправильно втілює свою політику, не забезпечує населення, засуджувала ті заходи кі торкались матеріального боку населення, наприклад: робкоопівське постачання, відсутність товарів та продовольства. Аналогічні розмови були також з боку їі чоловіка та чоловіка його сестри [1, с.28]. 
Вже 23 грудня було заарештовано Конюшинського Володимира Савельовича за антирадянську агітацію в якості звинуваченого. Сам Конюшинський Володимир Савельович, росіянин в 1894 р. народився в с.Катарусино Одеського району Одеської області, в родині безземельного селянина Подольської губерні Ямпольского уїзду. В 1910p. його батька, як хворого паралічем з села Понятовка звільнили та перевезли в м. Одесу до старшого сина Миколи Коншинському, який працював в цей час діловодом в електротехнічному училищі Гадзяцького, а Валодимир Савельович в цей час навчався в залізничному училищі на ст.Роздільна. Внаслідок відсутності коштів, змушений був полишити навчання та повернувся до Одеси до брата. саме в цей час помирає батько. Вступив чорноробочим на ПівденноОдеський пивоварений завод з утриманням 50 коп на день, в родині було 6 чоловік: три брати та три сестри.. В 1931 р. помирає брам Микола в Зінов’євську молодший брат розстріляний австро-німцями в 1918 р. в м.Вінниця за приналежність до партії більшовиків. В 1913 р. переїхав до свого зятя Вороновічу Олександру Івановичу в с.Устиновку Єлісаветградського уїзду(Зінов'євськ), де він працював на посаді писаря, а він його помічником. В 1914p. зятя переводять волостним писарем в с.Вавілово Херсонського уїзду, куди і він поїхав. В 1914p. як сотник ополчення 2 розряду мобілізований Херсонським військовим присутствієм i призначений в м.Кишинев в 40 запасний батальон, через два місяці його призначили в маршеву роту та відправили на німецький фронт молодшим ротним писарем, де і пробув до 1917 р. Після революції при тимчасовому уряді залишає фронт і повертається до Одеси. Брат в цей час працював в команді виздоравлюючих писарем і його влаштував на 275 санітарний потяг діловодом, який їздив маршрутом Одеса-Яси. Увесь потяг перейшов у відання Революційного штабу Південно-Західної залізниці. Став начальником потягу і відвозив поранених червоноармійців до Москви. При поверненні почав працювати при білих в карному рошуці в якості молодшого інспектора розшуку. В 1920p. Одеським воєнкомом Конюшинський 
Володимир Савельович призначений діловодом в Більчанський військомат, а потім військовим керівником. Губрозшуком відкликаний та призначений співробітником уїздного розшуку в 3-й район, в с.Севериновка, згодом завідуючим слідчою частиною де і був заарештований. В 1922p. був засуджений ревтрибуналом на 10 років за службу при білих в карному розшуку. Після виходу з Одеського ДОПру поїхав до своєї сестри в с.Олександрівка Миколаївського району де і одружився. В селі працював завюрстомом при сільбуді, а згодом і завідуючим сільбудом. В 1924p. 3 с.Олександрівка переїхав в м.Миколаїв де почав працювати в редакції «Червоний Миколаїв»в якості агента 3 підписки та поширення. Через три місяці ступив кам'янером на Ракетний завод. В 1926р. працював в Миколаївському лото в якості «галасуна». Після закриття лото поїхав до Кривого Рогу продовжуючи працювати в лото, але і там через 4 місяці лото закрилось. Вступив буфетником в робкооп руднику ім.Карла Лібкнехта. Внаслідок відсутності знань торгівлі вступи до Криворізької окрміліції завідуючим особовим складу. Через три місяці залишив службу і повернувся до Миколаєва. В 1930p. був під слідством ДПУ за звинуваченням ст.54-10 за приховування прапорщицького звання, але був звільнений. Вступив на завод «ім.61 комунара» теслярем, де через 4 місяці не витримав фізичного навантаження перейшов на посаду табельника, згодом справовода де пропрацював до 25 серпня 1932p. За пияцтво був звільнений та пішов працювати 3 зернорадгосп ім.Косіора рахівником в майстерні де і пропрацював з 4 вересня 1932 р. до 22 грудня 1932 р. - часу взяття під варту[1,с.30]. Одружений з Шесточенко Лідією Миколаївною, яка працювала табельницею на тракторній базі. Мав сестер: Березовську Віру Савелівну домогосподарка, Солів’єву Лідію Савелівну, мешкала в Одесі, також домогосподарка. Дружина брата Миколи Юлія та її дитина мешкали в Одесі.

При допиті його дружини Шесточенко (Конюшинська) Лідії Миколаївни, яка під час слідства 3 ним розлучилась, заявила, що Конюшинський В.С. - підозріла і «темна» особистість. Про себе іноді 
заявляв, він син ісправника, бувший офіцер, служив у білих, працював в контррозвідці, за що був засуджений до вищої міри покарання - розстрілу. Налаштований антирадянськи, часто критикував сучасний стан справ, звинувачував у всьому радянську владу. Причому точно антирадянських розмов вона навести не могла. Зазначала, що часто пиячив, а звідки брав кошти - невідомо, можливо крав на заводі матеріали, але це лише припущення. Пізніше Конюшинський В. С. все це у своїх показаннях спростовував.

Внаслідок всіх процесуальних дій у вироку слідчі зазначили, що було наявне угруповання антирадянських елементів і особливо активними серед них були Шесточенко Серафім Миколайович та його дружина Шесточенко Марія Іванівна, чоловік сестри Шесточенко С.М. - Конюшинський Володимир Савельович. Склад злочину полягав в тому, що «..вели між собою i серед своїх знайомих i колег по роботі антирадянські розмови i контрреволюційну агітацію, засуджуючи дії радянського уряду та заходи влади як в місті, так і на селі і взагалі все радянське, проклинаючи існуючу владу та їі порядки і висловлювали надію на зміну влади, очікували таке від білогвардійців із-за кордону за допомогою інтервенції....» [1,c.39]. Також зазначалось, що «...агітуючи за зміну радянської влади та білогвардійську інтервенцію, пов’ язуючи свою контрреволюційну агітацію з гострою формою антисемітизму, чим спонукали окремих осіб як проти радянської влади i диктатури пролетаріату в цілому, так і в окремих заходах радянського уряду і розпалювали міжнаціональну ворожнечу, тобто в злочинах, передбачених ст.54-10 КК УРСР» $[1$, с.47].

За зібраними матеріалами було винесено вирок уповноваженим ОВ Алютіним, ВР пом нач. НГО ДПУ Клявіним і нач. НГО ДПУ Ленським застосувати:

1. До звинуваченого Шесточенко Серафіма Миколайовича - вищу міру соціального захисту - розстріл; 
2. До звинуваченого Конюшинському Володимиру Савельовичу - вищу міру соціального захисту - розстріл;

3. До звинувачуваної Шесточенко Марії Іванівни - п’ять років концентраційних таборів.

У вироку зазначалось, що речових доказів за справою немає. Тобто лише за усними звинуваченнями та свідченнями людей засудили до смерті та тривалого терміну ув'язнення. Після розгляду особливої наради при колегії ДПУ УРСР 16 лютого 1933 р. було винесено остаточний вирок, за яким Шесточенко Серафіма Миколайовича було ув'язнено в концентраційний табір на 3 роки [1, с.64]; Конюшинському Володимира Савельовича ув'язнено в концентраційний табір на 3 роки[1, с.65]; Шесточенко Марію Іванівну з під варти звільнити, а справу припинити $[1, \mathrm{c.66}]$.

Відповідно з висновками прокурора Миколаївської області старшого радника юстиції Ю.Б. Бондаря від 30 червня 1989 р. Шесточенко Серафім Миколайович , Конюшинський Володимир Савелійович підпадає під дію ст.1 Указу Президії Верховної ради СРСР від 16 січня 1989 р. «Про додаткові заходи по відновленню справедливості по відношенню жертв репресій, які мали місце в період 30-40-х і початку 50-х років. Також було визначено, що Шесточенко M.I. була безпідставно притягнута до кримінальної відповідальності з політичних мотивів, вона підлягає реабілітації.

Досліджена справа продемонструвала загальну схему діяльності каральних органів, коли пригадувалось як звинувачення походження 3 заможної родини, або участь в революційних подіях не на боці переможців. На підставі досліджених справ стає цілком зрозуміло, що вся система судочинства щодо українців була побудована таким чином, аби доказова база відігравала допоміжну і не обов'язкову частину судочинства, а головним було те що людина була українцем, хліборобом, вела самостійне господарство, намагалась за будь-яку ціну зберегти відокремлене господарство, намагалась критично мислити та давати свою власну оцінку триваючим перетворенням суспільного життя. В значній мірі це була свого 
роду помста за минулу діяльність. Фактично думки ставали одним із доказів вини підсудних. Нажаль ми стали свідками такого ганебного явища, як звинувачення своїх родичів, друзів. Одні українці засвідчували брехню стосовно інших. Таким чином, дослідження засвідчує, що крім політики голодомору радянська система застосувала також відкриту репресивну політику щодо українського населення. На сьогоднішній день задокументовано 2008 справ громадян Миколаївщини які потрапили в лещата терору, збереглись їх кримінальні справи. Досліджуючи трагічні події 1932-1933-х років автора вражають масштаби людських втрат, причому за кожною цифрою стоїть окрема людина, іï життя, сподівання, розчарування і страшна трагедія смерті. Остаточна кількість втрат і по сьогодні залишається дискусійною. Наше суспільство повинно не просто пам'ятати, а уважно досліджувати, відстежувати, узагальнювати сучасні демографічні процеси в українському суспільстві. Постійно пам'ятаючи про від 3,5 до 9 млн замордованих впродовж двох років радянською тоталітарною системою треба також аналізувати статистику кількості населення сьогодні, адже, наприклад, лише за дев'ять місяців поточного 2016 року лише в Миколаївській області населення скоротилось на 5,3 тисячі чоловік і це без запровадження страшної політики голодомору, без врахування мігрантів тобто лише за цей період населення Миколаївщини скоротилося на 2-3 села.

Пам'ять про покладені жертви українства на алтар радянського режиму потрібно зберігати і використовувати у вихованні нових поколінь нашої вільної і самостійної держави. Злочинців, які втілювали нелюдські рішення теж треба назвати поіменно і віддати належне на стіні ганьби. Тому потрібно продовжувати дослідницьку роботу за існуючими документами кримінальних справ та зібраних усних свідченнях.

\section{ДЖЕРЕЛА ТА ЛІТЕРАТУРА}

1. Державний архів Миколаївської області (далі ДАМО). Ф.Р-5859. Оп.2. Спр.6359. Арк.1-70. 
2. ДАМО. Ф. Р-5859. Оп. 2, спр. 430, арк.1-19.

3. ДАМО. Ф. Р-8. Оп. 1. Спр. 201. Арк.28.

4. ДАМО. Ф. Р-8. Оп. 1. Спр. 266.Арк.10.

5. ДАМО. Ф. Р-1483. Оп. 1. Спр. 44. Арк.12.

6. ДАМО. Ф. Р-261. Оп. 1. Спр. 3. Арк.141.

7. ДАМО. Ф. Р-256. Оп. 1. Спр. 323. Арк.8.

8. ДАМО. Ф. Р-908. Оп. 1. Спр. 44. Арк.2.

9. ДАМО. Ф. Р-1311. Оп. 1. Спр. 24. Арк.156.

10. ДАМО. Ф. Р-472. Оп. 3. Спр. 16. Арк.123.

11. ДАМО. Ф. П-6. Оп. 1. Спр. 274. Арк.15-19.

12. ДАМО. Ф. П-30. ОП. 22. Спр. 8. Арк.15-16.

13. ДАМО. Ф. П-83. Оп. 1а. Спр. 8. Арк.7-19.

14. ДАМО. Ф. П-13. Оп. 1. Спр. 4. Арк.6,13.

15. ДАМО. Ф. П-130. Оп. 1а. Спр. 27. Арк.1-3.

16. ДАМО. Ф. П-2878. Оп. 1. Спр. 1. Арк.32-35.

17. ДАМО. Ф. П-129. Оп. 1а. Спр. 29. Арк.12-13.

18. ДАМО. Ф. Р-1191. Оп. 1. Спр. 3.Арк.180-189.

19. ДАМО. Ф. Р-687. Оп. 1. Спр. 195. Арк.25-26.

20. ДАМО. Ф. Р-1230. Оп. 1. Спр. 70. Арк.140.

21. ДАМО. Ф. Р-645. Оп. 1. Спр. 5. Арк.1.

22. ДАМО. Ф. Р-1391. Оп. 1. Спр. 2. Арк.151.

23. ДАМО. Ф. Р-1014. Оп. 1. Спр. 35. Арк.180.

24. ДАМО. Ф. Р-1187. Оп. 1. Спр. 31. Арк.36.

25. ДАМО. Ф. Р-950. Оп. 1. Спр. 15. Арк.8.

26. ДАМО. Ф. Р-1454. Оп. 1. Спр. 12. Арк.105-106.

27. ДАМО. Ф. Р-5859. ОП. 2. Спр. 620. Арк.8-9.

28. ДАМО. Ф. Р-5859. Оп. 2. Спр. 654. Арк.8-12.

29. ДАМО. Ф. Р-5859. Оп. 2. Спр. 655. Арк.8-16. 
30. Бахтін А.М. Наслідки голодомору в південних областях України // Гуманітарно-економічні дослідження: 36. наук, праць. Миколаїв; Одеса, 2005. T.2. C. 299-309.

31. Бахтін А.М. Причини голоду-геноциду в південному регіоні України // Гуманітарно-економічні дослідження: 36. наук, праць. Миколаїв; Одеса, 2005. Т.1. С.217-226.

32. Бахтін А.М. Репресивно-каральні заходи влади проти селян Півдня України у період голоду 1932-1933 років // Науковий вісник Миколаївського державного університету ім. В.О. Сухомлинського Миколаїв, 2005. Вип. 11. C.175-178.

33. Білокінь С. Масовий терор як засіб державного управління в СРСР: джерелознавче дослідження.Т.1. К., 1999.448 с.

34. Белоконь С. Механизм большевистского насилля. Конспект исследования. К., 2000.

35. В этом году в Николаевской области на 100 умерших приходилось 62 родившихся Николаев, Политика НикВести / 13:45, 17 Ноября, 2016 01055. Режим доступу: http://nikvesti.com/news/politics/97780

36. Вакулищин С. Чи був голодомор у Києві? К., 1997.

37. Гудима А. Кара без вини. К.: Урожай, 1993.

38. Голод 1932-1933 років на Україні: очима істориків, мовою документів /Упорядники: Р.Я.Пиріг та ін. К.: Вид-во політ. Літ-ри України., 1990. $605 \mathrm{c}$.

39. Голод-геноцид 1932-1933 років на території Миколаївщини: погляди істориків, очевидців, архівні матеріали (до 70-річчя трагедії) / Редкол.: О.М. Гаркуша (голова) та ін. Миколаїв: Вид-во ім. П. Могили, 2003. $200 \mathrm{c}$.

40. Друмов В.І. Документи про трагедію голодомору 1932-1933 pр. на Миколаївщині // Тези доповідей та повідомлень першої Миколаївської обласної краєзнавчої конференції, присвяченої 50-річчю Год Великої Перемоги. Миколаїв, 1995. С. 37. 
41. Конквест Р. Жнива скорботи. К., 1993. 249 с.

42. Кульчицький С.В. 1933: трагедія голоду. К., 1989. 50 с.

43. Кульчицький С.В. Україна між двома війнами (1921-1939 рр.). Т11. K., 1999.336 c.

44. Колективізація і голод на Україні: 1929-1933. Збірник матеріалів $\mathrm{i}$ документів/АН України. Інститут історії України та ін.: Упоряд.: Михайличенко Г. М., Шаталіна Є. П. ; Відп. ред.: Кульчицький С. В. Київ: Наукова думка, 1992. 736 с.

45. Козирева М.Е. Голод 1921-1923 pp. у німецьких колоніях на Миколаївщині // Наукові праці МФ НаУКМА. Миколаїв, 2001. Т.10. С. 89-92.

46. Кондратов В. Документальні свідчення про трагічні події вжитті селянства Миколаївщини наприкінці 20-х - на початку 30-х років // «Історія, Етнографія. Культура. Нові дослідження»: III Миколаїв, обл. краєзн. конф. Миколаїв, 2000. С. 341-343.

47. Котляр Ю.В. Ментальність південноукраїнського селянина i голодомор 1932-1933 років // Голодомор 1932-1933 років як величезна трагедія українського народу: Матер. Всеукр. наук. конф. К., 2003. С.185-190.

48. ЛіньовА., Шитюк М. Колективізація і голод 1929-1933 років на Миколаївщині // Щотижня. 1997. 31 трав.; 14, 28 черв.; 12, 26 лип.

49. Ліньов А.А. Колективізація та голод 1929-1933 років на території сучасної Миколаївщини // Україна в новомутисячолітті очима молодих фахівців. Миколаїв, 2000. С.54-60.

50. Марочко В. Бодай те лихо не верталось // Сучасність. 1993. №2.

51. Марочко В. Голодомор: біль і жах нашого народу // Культура i життя. 1990. 23 вересня.

52. Марочко В. Голодомор: причини і наслідки // Освіта. Спецвипуск. підручник. 1990. № 1, 2.

53. Марочко В. Голод на Україні (1931-1933pp.): причини і наслідки // Проблеми історії України: судження і пошуки. Вип.1. К., 1991. 
54. Марочко I.В., Шаталіна Є.П. Голод на Україні (1932-1933 рр.) // Український історичний журнал. 1989. №7-12; 1990. №1.

55. Макарчук С., Степаненко М. Голодомор на Миколаївщині // Рідне Прибужжя. 2000. 25 листоп.

56. Мельник М. Три голодомора // Наш город. 2007. 12-20 нояб. (№ 46). C. 18 .

57. Миколаївщина: колективізація сільського господарства і голод (1929-1933): Док. і матеріали / Авт. кол.: під керівництвом Шитюка М.М / МННЦ ОДУ ім. І.І.Мечникова, Держ. архів Миколаїв, обл. Миколаїв: Тетра, 2000. $212 \mathrm{c}$.

58. Національна книга пам'яті жертв голодомору 1932-1933 років в Україні. Миколаївська область. Миколаїв: Видавництво «Шамрай», 2008. $864 c$.

59. Не тільки про хліб: Голодомор-33 // Південна правда. 1991. 23 лют.

60. Никольчук Н. О голодоморе 1932-1933 гг. на Николаевщине // Южная правда. 2007. 24 нояб.

61. Не тільки про хліб: Голодомор-33 // Південна правда. 1991. 23 лют.

62. Про голод 1932-1933 років на Україні та публікацію пов'язаних 3 цим матеріалів // Комуніст України. 1990. №2.

63. Плясков Л. «Проступок...»: [Спогад про голодомор 1933 р.] // Південна правда. 1990. 23 груд.

64. Прусов П. Свідчення про геноцид 1932-33 років: // Губернская неделя. 2005. 6 дек.

65. Смертю смерть подолали: Голодомор в Україні 1932-1933 pp. / Панченко П.П., Литвин В.М., Шитюк М.М. К.: вид. України, 2003. 753 с.

66. ПлясковЛ. «Проступок...»: [Спогад про голодомор 1933 р.] // Південна правда. 1990. 23 груд.

67. Прусов П. Свідчення про геноцид 1932-33 років: // Губернская неделя. 2005. 6 дек. 
68. Садовничий $\quad$ В. Голодомор 1932-1933 pp. в Україні та на Миколаївщині // Україна в новому тисячолітті очима молодих фахівців. Миколаїв, 2000. С. 22-25.

69. Соболь П. Голод-геноцид 1932-1933 років на Миколаївщині: історіографічний аналіз// Гуманітарно- економічні дослідження: 36. наук, праць. Миколаїв; Одеса, 2005. Т.1. С. 162-173.

70. Соболь П. Голодомор 1932-1933 років: особливості соціальних патологій // Голодомор 19321933 років як величезна трагедія українського народу: Матер. Всеукр. наук. конф. К., 2003. С.164-173.

71. Серединський О. Голодомор 1932-1933 років на Миколаївщині // Вечерний Николаев. 2005. 26 нояб.

72. Серединський О. Голодомор 1932-1933 років: Документи Державного архіву Миколаївської області свідчать // Рідне Прибужжя. 2003. 27 берез.

73. Серединський О. Національна трагедія: 1932-1933pp.: [Миколаївський р-н] // Маяк. 2005. листоп.

74. Серединський О. Голодомор 1932-1933 років: [Арбузинський $\mathrm{p}-\mathrm{H}$ ]// Нове життя. 2005. 26 листоп.

75. Смугляков К. Люди вмирали, а хліб йшов на експорт // Радянське Прибужжя. 1993. 9 верес.

76. Столяров I. Річниця голодомору на Миколаївщині // Український Південь. 2002. 28 листоп. С.3.

77. Сторінки голодомору: За спогадами наших земляков // Щотижня. 1992. 21 лют. С. 7.

78. Толочик П. Хвилина немовчання: Сторінки щоденника із тридцять третього // Рідне Прибужжя. 2004. 30 листоп.

79. Трагедія століття: голодомор 1932-1933 років на Миколаївщині / Редкол.: О.М.Гаркуша (голова) та ін.; Миколаїв, облдержадмін. Миколаїв: Вид-во МДГУ ім. П.Могили, 2003. 471 с. 
80. Тригуб П. Трагедія у Пересадівці: Сторінка 3 історії голоду на Україні в 1932-1933 pp. // V Всеукраїнська конференція «Розвиток історичного краєзнавства в контексті національного i культурного відродження України». К.; Кам'янець-Подільський, 1991. С. 314-315.

81. У пам'яті навічно: [Голодомор 1932-1933 pp. у Доманівському р-ні] // Трибуна хлібороба. 2008. берез.

82. Федьков I. Голод 1932-1933 років на Миколаївщині // V Всеукраїнська конференція «Розвиток історичного краєзнавства в контексті національного i культурного відродження України». К.; Кам'янецьПодільський, 1991. С.312-313.

83. Фомін І. Випробування голодом // Щотижня. 1993. 8 трав. С. 7-8.

84. Фомін I. Слово про 33-ій рік: Спогади свідка // Голос Баштанщини. 1992. 10, 14, 17, 21 жовт.

85. Чорна книга України: зб. Документів, архів. Матеріалів, листів, доп., ст., досліджень, есе/Упоряд., ред.. Ф.Зубанича К.: Вид. центр «Просвіта», 1998. 784 с.

86. Чуніхін В. Голодомор // Південна правда. 1990. 28 листоп.

87. Чуніхін В. Дорогою сліз і смерті: [Голод 1932-1933 на Миколаївщині] // Ленінське плем'я. 1989. 18 черв.

88. Чунихин В. Черные зерна 1933 года // Николаевские новости. 1999. 10 нояб.

89. Холявко В. Голодомор 1932-1933 років: [Миколаївський р-н] // Маяк. 2007. 24 листоп.

90. Шитюк М. Голод 1932-1933 років на території Миколаївщини // Український Південь. 2005. 24листоп. 1 груд. (№45). С. 6.

91. Шитюк Н. Голод-геноцид 1933 года на территории Николаевщины: К 70-летию трагедии // Южная правда. 2003. Смугляков К. Люди вмирали, а хліб йшов на експорт //Радянське Прибужжя. 1993. 9 верес.

92. Шитюк М.М. Голод 1932-1933 років на території Миколаївщини в книзі. Голод-геноцид 1932-1933 рр. в Україні: історико-політологічний аналіз 
соціально-демографічних та морально-психологічних наслідків // Матеріали міжнародної конференції. К-Нью-йорк. 2000 С. 278-298.

93. Шитюк М.М., Бахтін А.М. Південна Україна: колективізація і голод (1929-1933 роки): Монографія. Миколаїв: Аскел, 2007. 512 с.

94. Шитюк М., Горбуров К. Миколаївщина в голодних 1921-1923, 19321933, 1946-1947 роках. Миколаїв: Вид-во І. Гудим, 2007. 155 с.

95. Шитюк М.М. Голодомори ХХ століття: 1921-1923, 1932-1933, 19461947. К.: Геліон, 1997. 60 с.

96. Шкварець В.П., Є.Г. Горбуров, К.Є. Горбуров. Історіософія та історіографія голодів-людоморів на Миколаївщині. Миколаїв: Шамрай, 2008. $288 \mathrm{c}$.

97. Шитюк M.M. Голод-геноцид 1932-1933 років на території Миколаївщини // Голодомор 1932-1933 років як величезна трагедія українського народу: Матер. Всеукр. наук. конф. К., 2003. С. 174-184.

98. Шитюк М.М. Голод-геноцид 1933 року: історико-політологічний аналіз соціально-демографічних та морально-психологічних наслідків на території Миколаївщини // Миколаївщина: літопис історичних подій. Херсон, 2002. C. 344-363.

99. 33-й: голод: Народна Книга-Меморіал / Упоряд.: Л. Б. Коваленко, В. А.Маняк К.: Рад. письменник. 1991. 584 с.

100. Історія рідного краю: Миколаївщина: навчальний посібник /М.М.Шитюк(кер. Авт.. кол.), О.О.Баковецька, Н.М.Буглай, М.М. Зеркаль та ін. Миколаїв: Іліон, 2015. 628 с.

Zerkal M.M. The repression of the peasants during the Holodomor 19321933. in Nikolaev: the fate of people.

Explores another embodiment the direction of the Ukrainian people genocide by the communist totalitarian regime on the basis of criminal cases that justify the use of criminal penalties to the mass of the rural population in 1932- 
1933. This issue is covered in the context of ethnic genocide of the Ukrainian people and the state party by law enforcement agencies.

Author emphasizes, the memory of the victims of Ukrainians laid on the altar of the Soviet regime should be stored and used in the education of new generations of our free and independent state. Criminals who put the inhuman decision must also be called by name and pay tribute to the wall of shame. Therefore it is necessary to continue research on existing documents of criminal cases and collected oral testimonies.

Key words: totalitarian system, the crime of genocide, famine, the party apparatus, the ideology of the peasantry. 